Int. J. Electrochem. Sci., 14 (2019) $7911-7924$

\title{
Simultaneously determination of bisphenol A and uric acid by zinc/aluminum-layered double hydroxide-2-(2,4- dichlorophenoxy) propionate paste electrode
}

\author{
Nurul Syahida Mat Rais ${ }^{1}$, Illyas Md Isa ${ }^{1,2}{ }^{*}$, Norhayati Hashim ${ }^{1,2}$, Mohamad Idris Saidin ${ }^{1,2}$, Siti Nur \\ Akmar Mohd Yazid ${ }^{l}$, Mohamad Syahrizal Ahmad ${ }^{l}$, Rahadian Zainul ${ }^{3}$, Suyanta ${ }^{4}$, Siriboon Mukdasai ${ }^{5}$ \\ ${ }^{1}$ Department of Chemistry, Faculty of Science and Mathemathics, Universiti Pendidikan Sultan Idris, \\ 35900 Tanjong Malim, Perak, Malaysia \\ ${ }^{2}$ Nanotechnology Research Centre, Faculty of Science and Mathemathics, Universiti Pendidikan \\ Sultan Idris, 35900 Tanjong Malim, Perak, Malaysia \\ ${ }^{3}$ Department of Chemistry, Faculty of Mathematics and Natural Science, Universitas Negeri Padang, \\ West Sumatera 25171, Indonesia \\ ${ }^{4}$ Deparment of Chemistry Education, Faculty of Mathematics and Natural Science, Yogyakarta State \\ University, Indonesia \\ ${ }^{5}$ Department of Chemistry, Faculty of Science, Khon Kaen University, Khon Kaen 40002, Thailand \\ *E-mail: illyas@ fsmt.upsi.edu.my
}

doi: $10.20964 / 2019.08 .75$

Received: 20 March 2019 / Accepted: 8 May 2019 / Published: 30 June 2019

\begin{abstract}
A novel zinc/aluminium-layered double hydroxide-2-(2,4-dichlorophenoxy) propionate (Zn/Al-LDHDPPA) nanocomposite to modify with multi-walled carbon nanotube (MWCNT) paste electrode for simultaneously determination of uric acid and bisphenol A. The Zn/Al-LDH-DPPA/MWCNT morphology was carried out by a scanning electron microscope and transmission electron microscope, electrode-electrolyte interface properties were examined by electrochemical impedance spectroscopy, and electrochemical responses thoroughly investigated by square-wave voltammetry. The electrode established linear plot for uric acid and bisphenol A from $5.0 \times 10^{-6} \mathrm{M}$ to $7.0 \times 10^{-4} \mathrm{M}\left(\mathrm{R}^{2}=0.9980\right)$ and $\left(\mathrm{R}^{2}=0.9960\right)$ and the detection limits were $7.95 \times 10^{-7} \mathrm{M}$ and $8.71 \times 10^{-7} \mathrm{M}(\mathrm{S} / \mathrm{N}=3)$. The asprepared sensor is reproducible, highly stable, sensitive as well as ascribed good anti-interference ability. The Zn/Al-LDH-DPPA/MWCNT electrode is applicable to evaluate simultaneously determination of UA and BPA in lake, river and, urine samples with good percentage recovery.
\end{abstract}

Keywords: Uric acid; bisphenol A; multi-walled carbon nanotube; square wave voltammetry; zinc layered double hydroxide 


\section{FULL TEXT}

(C) 2019 The Authors. Published by ESG (www.electrochemsci.org). This article is an open access article distributed under the terms and conditions of the Creative Commons Attribution license (http://creativecommons.org/licenses/by/4.0/). 